Annals of Tropical Research 41 (2):100-114(2019)

(c) VSU, Leyte, Philippines

\title{
Split crown technique for mass propagation of pineapple (Ananas comosus L.) var. queen
}

\author{
Sarah M. Ravelo* and Arsenio D. Ramos
}

\begin{abstract}
The major problem limiting large scale commercial production and/or expansion of pineapple production is the difficulty in obtaining large quantity of quality planting materials due to slow rate of multiplication by conventional methods of propagation that mostly relies on the use of suckers and slips.

The study investigated the effect of the methods of crown preparation on the sucker production of pineapple var. Queen and to evaluate the horticultural qualities of suckers produced from plantlets prepared using different methods of crown preparation.

Destroying the growing point without splitting reduced percentage survival of plantlets but destroying the meristem and splitting the crown into two or four sections improved survival comparable to the intact crown. Destruction of the growing point and then splitting the crown promoted emergence and increased the number of suckers relative to the intact crown, which did not produce suckers after 3 months from planting. Increasing the number of sections prepared per crown (from two to four) did not reduce the number of suckers produced per plantlet and thus increased the multiplication rate by 7 and 8 times, respectively.

The method of crown preparation did not significantly influence the early growth performance (survival, height, number \& size of leaves) of the harvested suckers during the first 6 months after potting. Among the three methods of crown preparation, destroying the meristem and splitting into two or four produced more number of ready-to-plant Queen pineapple suckers (1-ft tall) within a period of 5 months.
\end{abstract}

Keywords: Ananas comosus, crown preparation, sucker production, sucker quality

\section{INTRODUCTION}

The pineapple (Ananas comosus L. Merr) belongs to the Bromeliaceace family which comprises about 2,000 species (Purseglove 1975). It is one of the most

'Department of Horticulture, Visayas State University, Visca, Baybay City, Leyte 6521-A, Philippines

*Corresponding Author. Address: Department of Horticulture, Visayas State University, Visca, Baybay City, Leyte 6521-A, Philippines; Email: sarah_ravelo2008@yahoo.com 
Split crown technique for mass propagation of pineapple

important fruit crops produced in the country after banana (Espino \& Espino 2015, Balito 2011). While the pineapple fruits exported by the country were produced by big established multinational companies, the increasing local demand has encouraged more farmers to plant pineapple in semi-commercial scale. For example, the area planted with pineapple in the country increased from 58,251 ha in 2008 to 60,750 ha in 2013, which resulted to the production of $245,842 \mathrm{MT}$ in 2013 or average annual growth rate of $2.20 \%$ (Espino \& Espino 2015). The production of pineapple in 2016 was $2.61 \mathrm{MMT}, 1.2 \%$ higher from the previous year's level of 2.58MMT. This was attributed to the increase in area harvested from the expansion of corporate farms in Northern Mindanao (Philippine Statistics Authority 2016).

A major problem limiting large scale commercial production of pineapple and/or expansion of existing farms is the difficulty in obtaining large quantity of quality planting materials due to slow rate of multiplication by conventional methods of propagation that mostly relies on the use of suckers and slips. A hectare of pineapple farm requires between 40,000 to 60,000 planting materials. A most efficient way of propagating pineapple that is fast, assures uniform and clean planting materials (Firoozabady et al 2003, Swennen 1990) and also offers opportunity for varietal improvement (Sripaoraya et al 2003) is by in vitro technique. Plant tissue culture has been commercially used for rapid mass production of pineapple propagules (Rahman et al 2001, Firoozabady et al 2003, Abul-Soad et al 2006).

However, while proven efficient, in vitro technique of propagating pineapple is a sophisticated method of generating planting materials. It is also capital intensive and is not affordable by many small-scale pineapple farmers. Furthermore, the technology is not well developed in many pineapple growing regions in the country, including Region 8. There is, therefore, a need for the utilization of alternative methods of mass production of pineapple planting materials that is cost effective and simple (Lopez 1994).

There are several types of planting materials that can be used for pineapple propagation, including the slips which arises from the stock beneath the fruit, suckers originating from side shoots, crowns of the fruits and ratoons that come out of the underground part of the stems (Bartholomew et al 2003). These conventional propagation materials however, are usually in short supply and inadequate to meet planting materials requirement for large scale production, particularly. The need for large quantity of planting materials required for commercial or industrial use is difficult to achieve by conventional techniques, particularly when uniform planting materials are needed because of slow multiplication rate.

Efficient macro-propagation techniques of mass propagating Smooth Cayene pineapple variety through Split Crown Technique (SCT) was reported by Agogbua et al (2011) and Fitchet and Venter (1987). The procedures involved splitting the crowns into sections and damaging the meristem to release the axillary buds from the effect of apical dominance and planting the propagules in suitable medium. The technique has been found effective on crowns which are normally cut off and discarded after purchase of pineapple fruits which are potential sources of propagules for sucker generation. SCT is relatively cheaper than in vitro shoot-tip culture. The use of macropropagation method for increasing sucker multiplication of plantains and bananas at farm level has also been advanced in Nigeria (Baiyeri \& 
Aba 2005). A major advantage of the macropropagation technique is that it is not highly technical and does not require specialized skills. It is also very cost-effective and can be used to produce large-scale uniform materials in a relatively short period of time (Adelaja 2000).

The split crown technique was reported to be an efficient way of inducing sucker/plantlet production of pineapple var. smooth cayenne in Nigeria (Agogbua et al 2011). In the Philippines, there has been no report on the use of SCT as a means of macro-propagation of pineapple (particularly the Queen variety) which is commonly grown in Region 8 . Therefore, this study was conducted to evaluate the efficacy of split crown technique in the mass propagation of pineapple var. Queen.

\section{MATERIALS AND METHODS}

\section{Plant Material}

Fresh crowns of pineapple var. Queen were sourced out from fruit vendors at Ormoc City Public Market selling pineapple fruits from Larazabal Pineapple Farm. These were packed in cartons boxes and were carefully transported to Brgy. Guadalupe, Baybay City, Leyte, where the experiment was conducted.

\section{Preparation of Planting Material/Plantlet by Treatment}

A total of 132 crowns of more or less the same weight were used in the experiment. The crowns were prepared following four methods of preparation, including crown with growing point intact without splitting ( $\mathrm{T}_{1}$-control), crown with growing point destroyed without splitting $\left(T_{2}\right)$, crown with growing point destroyed and split into two sections $\left(T_{3}\right)$, and crowns with growing point destroyed and crown split into four sections $\left(\mathrm{T}_{4}\right)$.

For treatments which involved growing point destruction, the shoot apex (growing point) was partially removed with the use of sharp knife prior to crown splitting. The crowns were then split into two and four sections according to treatments (Figure 1). In this experiment, the planting materials prepared from the crown were named as plantlet.

\section{Experimental Design, Field Layout and Planting}

The study was laid out in a Randomized Complete Block Design (RCBD), with four replications having 12 samples per treatment in a replication.

The plantlets were planted using the double row planting. Two rows were spaced $60 \mathrm{~cm}$ apart and plantlets at $40 \mathrm{~cm}$ within the rows. The distance between the double rows (or every two rows) was $150 \mathrm{~cm}$. There were two rows per plot, with six plantlets per row. Plantlets were treated with fungicide (Bayleton) and insecticide (Diazinon) $0.1 \%-5 \mathrm{~mL}$ in $4.5 \mathrm{~L}$ water before planting by submerging the crowns for $20 \mathrm{~min}$, then draining off the excess solution to another container. 
Split crown technique for mass propagation of pineapple

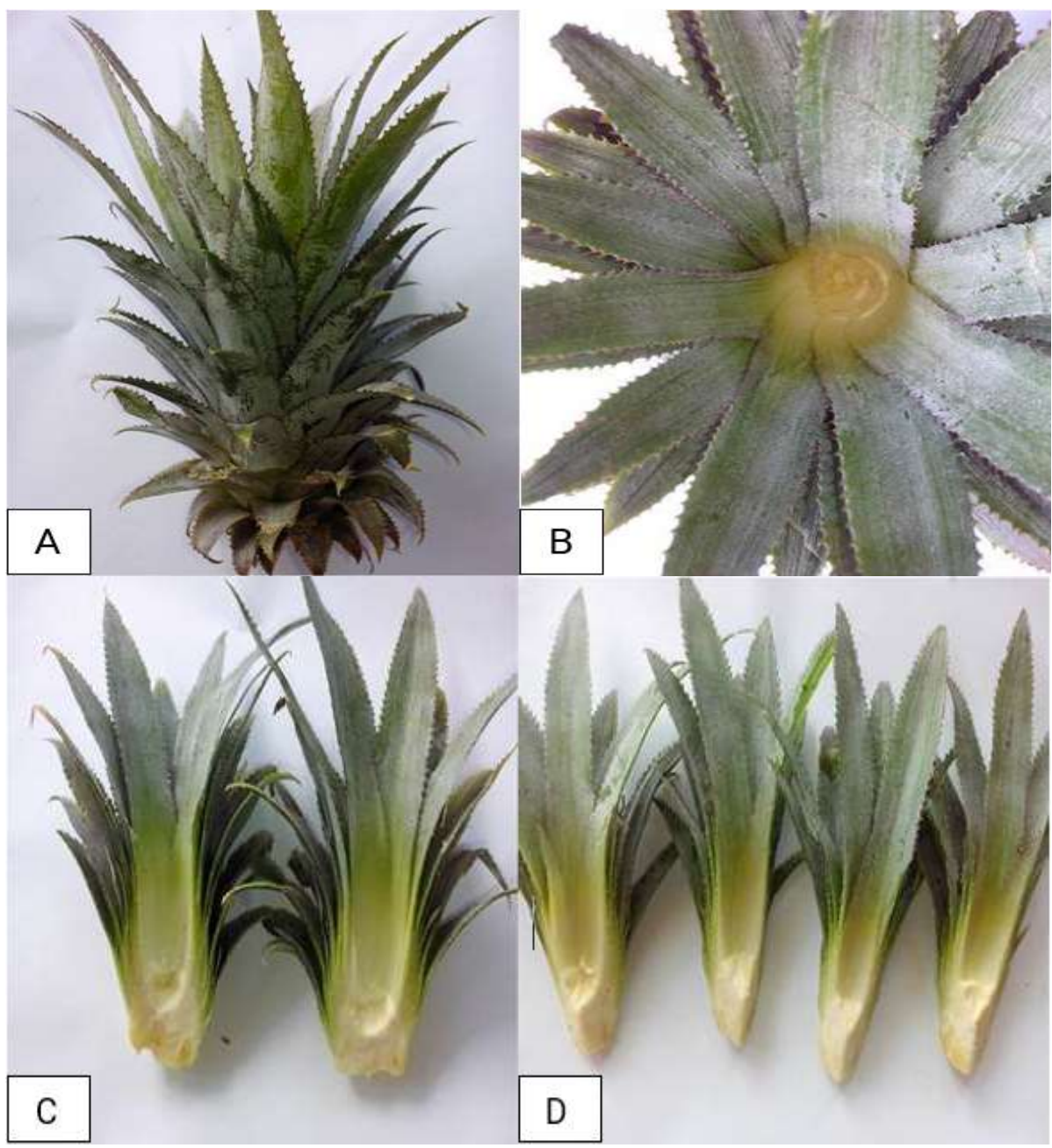

Figure 1.Crowns subjected to four treatments: $A)$ growing point intact $\left(\mathrm{T}_{1}\right.$-Control); $\left.\mathrm{B}\right)$ growing point destroyed without splitting $\left(\mathrm{T}_{2}\right)$; C) growing point destroyed crown split into two $\left(\mathrm{T}_{3}\right)$; $\left.\mathrm{D}\right)$ growing point destroyed crown split into four $\left(\mathrm{T}_{4}\right)$

\section{Cultural Practices Implemented}

Supplemental watering was done once a week but during dry weeks, the plants were watered three times a week. The weeds were controlled by directed spraying using Top Ace, a pre-emergence herbicide, at the rate of $200 \mathrm{~mL}$ per $16 \mathrm{~L}$ water after planting and by spot weeding. As a precautionary measure against phytopthora and mealybug, a mixture of Alliete $(10 \mathrm{~mL}$ per $16 \mathrm{~L}$ water $)$ and Parapest $D(10 \mathrm{~mL}$ per $16 \mathrm{~L}$ water) and Hoestick were sprayed on the soil after planting. Complete fertilizer was applied at the rate of $28 \mathrm{~g}$ per plant by basal application, two weeks after planting and at two weeks interval. 


\section{Harvesting of Suckers}

The harvesting was done by separating/detaching the emerging suckers from the plantlets three months after planting or when about $7-10 \mathrm{~cm}$ long suckers were developed. The suckers were carefully detached from the plantlet by a combination of slight twisting and pulling until these were totally separated from the plantlet.

\section{Potting and Care of the Harvested Suckers}

The harvested suckers were potted in polybags with a rim base diameter of $12.7 \mathrm{~cm}$, having a potting medium composed of garden soil, sand, and compost with a ratio of 2:1:1 ( $/ / \mathrm{v} / \mathrm{v})$. Complete fertilizer 14-14-14 (at the rate of $28 \mathrm{~g}$ per pot) was applied to provide nutrients to plants and enhance their growth and development. The potted suckers were then maintained under a local nursery shade, with temporary roofing made of a layer of coconut leaves for two months, after which the shade was removed to expose the plants to full sunlight. The plants were maintained under full sunlight for additional four months for monitoring their growth performance.

\section{Data Gathered}

1.Survival of planted plantlet - this was performed 2 months after planting the planting material and computed using the formula:

$$
\% \text { survival }=\frac{\text { No. of plantlets survived }}{\text { Total no. of plantlets }} \times 100
$$

2.Number of days from planting to the emergence of sucker - this was determined by counting the number of days from planting to the emergence of the first sucker.

3.Survival of potted sucker (\%)- this was performed 2 months after transplanting in pots and computed using the formula:

$$
\% \text { survival }=\frac{\text { No. of potted sucker survived }}{\text { Total no. of potted sucker }} \times 100
$$

4. Number of suckers produced per plantlet - this was determined by counting the suckers produced per plant three months after planting.

5. Multiplication rate per 100 crowns - this was done by multiplying the average number of suckers produced per plantlet by the number of sections produced per crown and then multiplying by 100 .

6. Size/weight of sucker - this was determined by weighing the harvested sucker before transplanting.

7. Average number of roots/sucker - this was determined by counting the number of roots from the emerged suckers during sucker harvesting

8. Sucker orientation - this was determined by observing the direction of emerging sucker if it is erect or clasping to the mother plant.

9. Growth performance of potted sucker - this was determined by gathering data on height, no. of leaves, length and width of leaves at 2, 4, and 6 months after potting. 
Split crown technique for mass propagation of pineapple

\section{Statistical Analysis}

The data were analyzed statistically using the software Statistical Tool for Agricultural Research (STAR), version 2.0.1.2015. Significant differences among treatments were determined using Analysis of Variance (ANOVA) arranged in Randomized Complete Block Design (RCBD). Comparison of treatment means was performed using Least Significant Difference (LSD) at $5 \%$ level of significance.

\section{RESULTS AND DISCUSSION}

\section{Weight of Crown before Planting/Splitting}

Pineapple crowns that (would otherwise have been left to waste after purchase or utilization of edible part of the fruits) were used to produce planting material (suckers) of pineapple var. Queen. More or less uniform-sized crowns with weight ranging from $120-180 \mathrm{~g}$ were selected.

\section{Survival of Planted Crowns and Number of Days to Sucker Emergence}

Table 1 shows the percent survival of plantlets and the number of days to sucker emergence. Destruction of the growing point and splitting of the crown significantly affected survival and the emergence of suckers from the plantlet. The control crowns had $100 \%$ survival but was only comparable with the percentage survival of crowns with growing point destroyed and split into two $\left(T_{3}\right)$ or four sections $\left(T_{4}\right)$. The un-split crown with growing point destroyed $\left(T_{2}\right)$ had the lowest percentage survival (87.5\%), which was significantly lower than crowns prepared using $T_{1}, T_{3}$ and $T_{4}$.

The un-split crown with growing point destroyed $\left(T_{2}\right)$ had the lowest percent survival due to rotting of the wounded part of the apex. During the conduct of the study there were weeks with heavy rainfall which resulted in the accumulation of water in the central portion of the apex where the growing point was excised, causing rotting and in severe cases death of the plantlet. Rotting was probably caused by pathogens that cause pineapple heart rot disease. Heart rot, a pineapple disease caused by Pythium and Phytophthora, caused rotting of the basal leaf tissue (Bartholomew et al 2003) which is more severe in high rainfall areas and in areas with poor soil drainage (Green \& Nelson 2015).

Table1. Percent survival and number of days to sucker emergence of plantlets of pineapple var.

\begin{tabular}{lcc}
\hline \multicolumn{1}{c}{ Treatments } & \% Survival & $\begin{array}{c}\text { No. of days to sucker } \\
\text { emergence }\end{array}$ \\
\hline $\mathrm{T}_{1}-$ control: growing point intact & $100 \mathrm{a}$ & - \\
& & $52.75 \mathrm{a}$ \\
$\mathrm{T}_{2}-$ growing point destroyed without & $87.5 \mathrm{~b}$ & \\
splitting crowns & & \\
$\begin{array}{l}\text { Means in column with the same letter are not significantly different at } 5 \% \text { level LSD }(-) \text { no sucker produced } 2 \text { months after } \\
\text { planting }\end{array}$
\end{tabular}


Table 1 continued

\begin{tabular}{ccc}
\hline \multicolumn{1}{c}{ Treatments } & \% Survival & $\begin{array}{c}\text { No. of days to sucker } \\
\text { emergence }\end{array}$ \\
\hline $\begin{array}{c}\mathrm{T}_{3}-\text { growing point destroyed and crown split } \\
\text { into two sections }\end{array}$ & $97.9 \mathrm{a}$ & $42.5 \mathrm{c}$ \\
$\begin{array}{l}\mathrm{T}_{4}-\text { growing point destroyed and crown split } \\
\text { into four sections }\end{array}$ & $97.9 \mathrm{a}$ & $46.5 \mathrm{~b}$ \\
\hline $\mathrm{CV}(\%)$ & 4.10 & 1.69 \\
\hline
\end{tabular}

Means in column with the same letter are not significantly different at $5 \%$ level LSD (-) no sucker produced 2 months after planting

On the number of days to sucker production, the crowns that were splitted into two without destroying their growing point $\left(T_{3}\right)$ exhibited earlier emergence (42.5 days), while crowns with growing point destroyed and split into four sections $\left(T_{4}\right)$ in 46.5 days. The sucker emergence of crowns with growing point destroyed but without splitting $\left(T_{2}\right)$ occurred 52.75 days, while the control did not produce suckers. The result indicated that growing point removal and splitting of the crown promoted early suckering of the plantlets, as shown by the failure of the intact plantlets $\left(\mathrm{T}_{1}\right)$ to produce suckers three months after planting. Delayed suckering in $T_{4}$, relative to $T_{3}$, could be attributed to the smaller plantlets which only contain limited supply of food needed for sucker development.

The inhibition of suckering in pineapple var. Smooth Cayene was reported by Agogbua and Osuji (2011) to have been caused by the suppression of lateral bud growth by auxin produced by the shoot apex a phenomenon known as apical dominance. Pineapple var. Smooth Cayene has strong apical dominance inhibiting the development of axillary buds (Bartholomew et al 2003). The results of the present study also indicated that in pineapple var. Queen, apical dominance was the factor that inhibited sucker development of the planted crown and that destruction of growing point and splitting of the crown which eliminated apical dominance promoted lateral sucker development. Spirko et al (2015) reported that dormant buds of plant species that exhibited axillary bud dormancy were broken by destroying the apical meristem (or actively growing stem tip) which produced auxin that suppressed axillary bud growth (Gocal et al 1991).

\section{Average Number of Suckers Produced and Multiplication Rate Per 100 Crowns}

Figure 2 shows the average number of suckers harvested from the individual plantlet, three months after planting. The un-split crown with growing point destroyed $\left(T_{2}\right)$ had the most suckers (4.25) produced per plantlet, although was statistically comparable to number of suckers produced by the crowns with growing point destroyed and split into two sections $\left(T_{3}\right)$, with 3.55 suckers per plantlet. The crowns with growing point destroyed and split into four sections had the least sucker produced ( 2.2 sucker/plantlet) but was just comparable with $T_{2}$. The intact plantlet $\left(\mathrm{T}_{1}\right)$ did not produce suckers. 
Split crown technique for mass propagation of pineapple

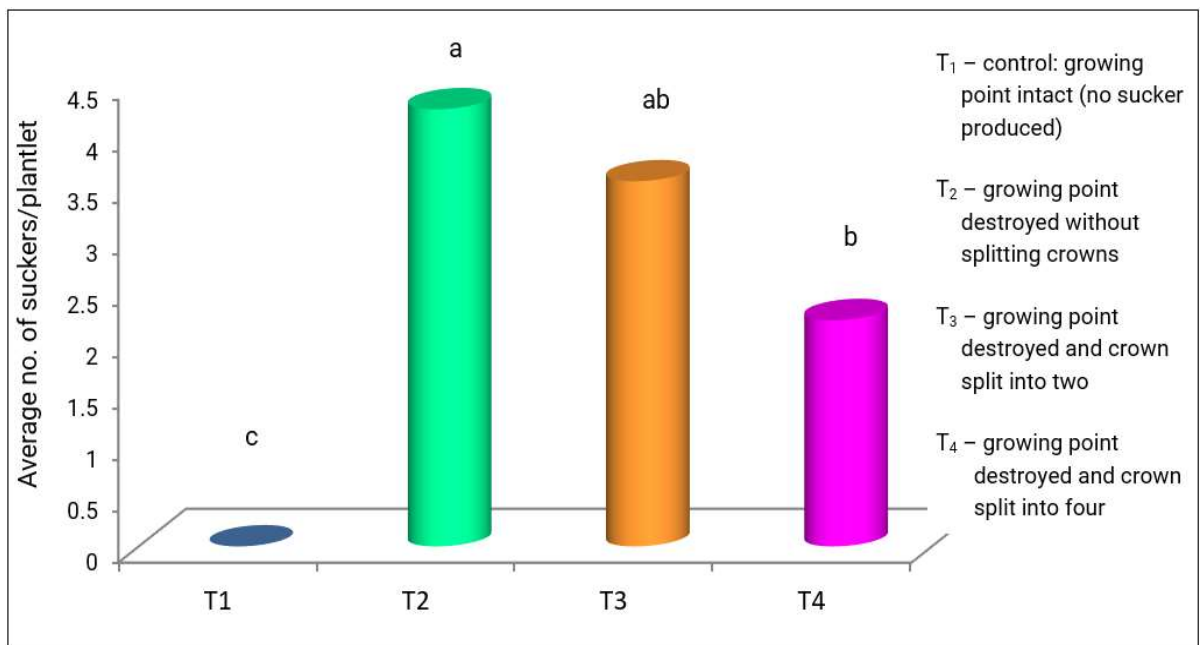

Figure 2. Average number of produced suckers from pineapple var. Queen crown subjected to 4 methods of crown preparation

The more suckers produced by the bigger plantlets over those of the small ones was primarily attributed to more lateral buds, which later developed into suckers. It was noted however, that splitting the crown into two did not significantly reduce the number of suckers produced per plantlet.

In terms of multiplication rate per 100 crowns, crowns subjected to splitting into $4\left(T_{4}\right)$ produced the highest number of suckers (800) per 100 crowns, which significantly outnumbered the number of suckers produced by the crown that was split into $2\left(T_{3}\right)$, having 700 suckers and in $T_{2}(440)$. Sucker production of $T_{2}$ and $T_{3}$ were just comparable but significantly higher than $\mathrm{T}_{1}$ (Figure 3 ). The superior sucker production in $T_{4}$ over $T_{1}, T_{2}$ and $T_{3}$ can be explained by the minimal effect of splitting on the number of suckers produced per plantlet (Figure 2) such that the more sections prepared per crown, the more suckers were produced.

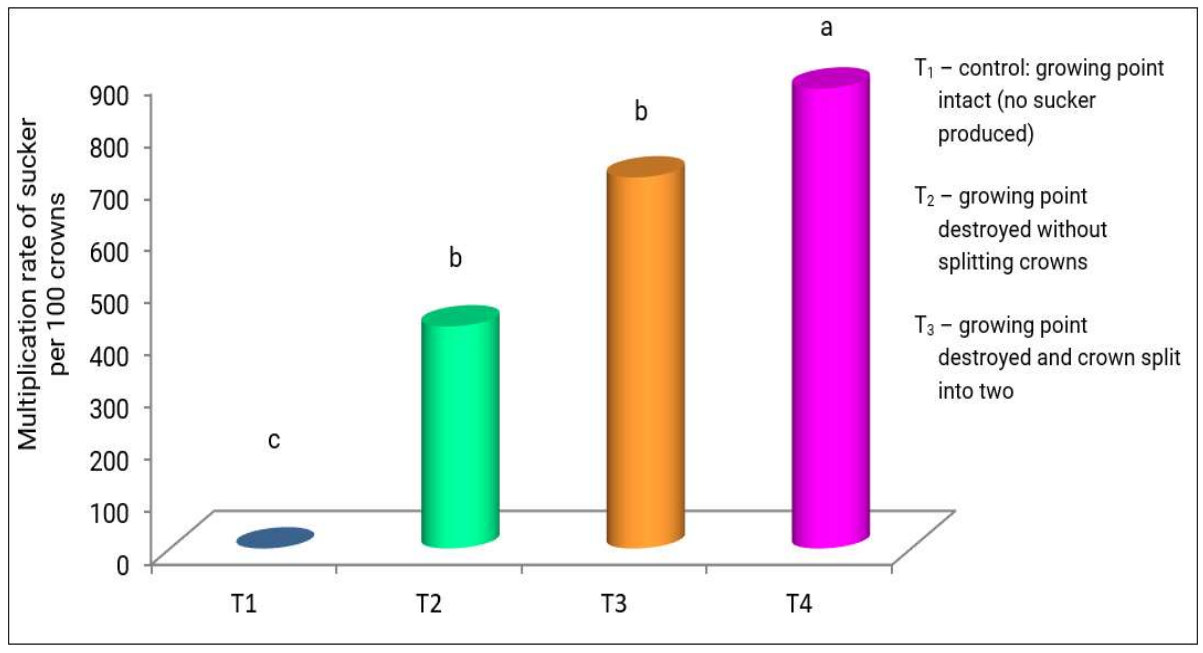

Figure 3. Multiplication rate of produced suckers from pineapple var. Queen crown subjected to 4 methods of crown preparation 
In pineapple var. Smooth Cayene, growing point destruction or decapitation and splitting of the crown also successfully increased sucker production (Bartholomew et al 2003, Agobua \& Osuji 2011, Fitchet \& Venteer 1987). Growing point destruction has also improved sucker production in other crops, including taro (Pardales \& Dalion 1986) and banana (FAO 2010).

\section{Horticultural Characteristics of Sucker Produced}

Table 2 shows the horticultural characteristics of harvested suckers. Weight of suckers and, number and width of leaves were not significantly affected by the method of crown preparation but the sucker height, leaf length and number of roots significantly differed among treatments. Numerically, suckers harvested from the un-split crown with excised growing point $\left(T_{2}\right)$ were the heaviest $(37.5 \mathrm{~g})$, followed by suckers produced by the crown with growing point destroyed and split into four sections $(27.4 \mathrm{~g})$, while the lowest were from the crowns having growing point destroyed and split into two (25.4g). Regardless of the kind of plantlet, the suckers had an average of 7 to 7.75 leaves that are 2.0 to $2.57 \mathrm{~cm}$ wide.

On the other hand, suckers harvested from $\mathrm{T}_{2}$ were significantly taller than those harvested from $T_{3}$ and $T_{4}$ which had comparable height (Figure 4). Furthermore, suckers from $T_{2}$ had significantly longer leaves compared to suckers harvested from $T_{3}$ and $T_{4}$. The taller suckers harvested from $T_{2}$ compared to that from $T_{3}$ and $T_{4}$ could be a result of more food reserved in the bigger un-split plantlet. On the number of roots/sucker, those harvested from $\mathrm{T}_{2}$ and $\mathrm{T}_{3}$ had comparable number of roots which were significantly fewer than those produced by suckers harvested from $\mathrm{T}_{4}$. The result could be possibly an effect of ethylene on adventitious root production. The process of meristem destruction and splitting of the crown into sections both inflected wounds which may have caused an increase in ethylene production of the injured tissue of the crown. Ethylene at certain concentration has been reported to enhance adventitious root formation in many plant species (Roy et al 1972, Negi et al 2010), including mungbean hypocotyl cuttings (Pan et al 2001) and sunflower cuttings (Liu et al 1990).

Table 2. Horticultural characteristics of produced suckers from pineapple var. Queen crown subjected to 4 methods of crown preparation

\begin{tabular}{|c|c|c|c|c|c|c|}
\hline \multirow[b]{2}{*}{ Treatments } & \multicolumn{6}{|c|}{ At Transplanting } \\
\hline & $\begin{array}{l}\text { Average } \\
\text { Weight of } \\
\text { suckers } \\
\text { (g) }\end{array}$ & $\begin{array}{l}\text { Plant } \\
\text { height } \\
(\mathrm{cm})\end{array}$ & $\begin{array}{l}\text { No. of } \\
\text { leaves }\end{array}$ & $\begin{array}{l}\text { Leaf length } \\
\qquad(\mathrm{cm})\end{array}$ & $\begin{array}{l}\text { Leaf width } \\
\quad(\mathrm{cm})\end{array}$ & $\begin{array}{l}\text { Average } \\
\text { No. of } \\
\text { roots/sucker }\end{array}$ \\
\hline $\begin{array}{c}\mathrm{T}_{1}-\text { control: growing } \\
\text { point intact }\end{array}$ & - & - & - & - & - & - \\
\hline $\begin{array}{l}\mathrm{T}_{2}-\text { growing point } \\
\text { destroyed without } \\
\text { splitting crowns }\end{array}$ & 37.5 & $25.77 a$ & 7.25 & $23.18 a$ & 2.35 & $2.34 b$ \\
\hline $\begin{array}{l}\mathrm{T}_{3}-\text { growing point } \\
\text { destroyed and crown } \\
\text { split into two }\end{array}$ & 25.4 & $21.73 b$ & 7.00 & $19.50 \mathrm{~b}$ & 2.20 & $2.27 \mathrm{~b}$ \\
\hline
\end{tabular}

Means in column with the same letter are not significantly different at $5 \%$ level LSD

$(-)$ no sucker produced 
Split crown technique for mass propagation of pineapple

\begin{tabular}{lcccccc} 
Table 2 continued & \multicolumn{7}{c}{ At Transplanting } \\
\cline { 2 - 7 } Treatments & $\begin{array}{c}\text { Average } \\
\text { Weight of } \\
\text { suckers } \\
(\mathrm{g})\end{array}$ & $\begin{array}{c}\text { Plant } \\
\text { height } \\
(\mathrm{cm})\end{array}$ & $\begin{array}{c}\text { No. of } \\
\text { leaves }\end{array}$ & $\begin{array}{c}\text { Leaf length } \\
(\mathrm{cm})\end{array}$ & $\begin{array}{c}\text { Leaf width } \\
(\mathrm{cm})\end{array}$ & $\begin{array}{c}\text { Average } \\
\text { No. of } \\
\text { roots/sucker }\end{array}$ \\
\hline $\begin{array}{l}\mathrm{T}_{4}-\text { growing point } \\
\text { destroyed and crown } \\
\text { split into four }\end{array}$ & 27.4 & $20.65 \mathrm{~b}$ & 7.75 & $18.52 \mathrm{~b}$ & 2.57 & $2.78 \mathrm{a}$ \\
\hline $\mathrm{CV}(\%)$ & 28.56 & 9.09 & 12.24 & 7.58 & 12.09 & 8.60 \\
\hline
\end{tabular}

Means in column with the same letter are not significantly different at $5 \%$ level LSD

$(-)$ no sucker produced

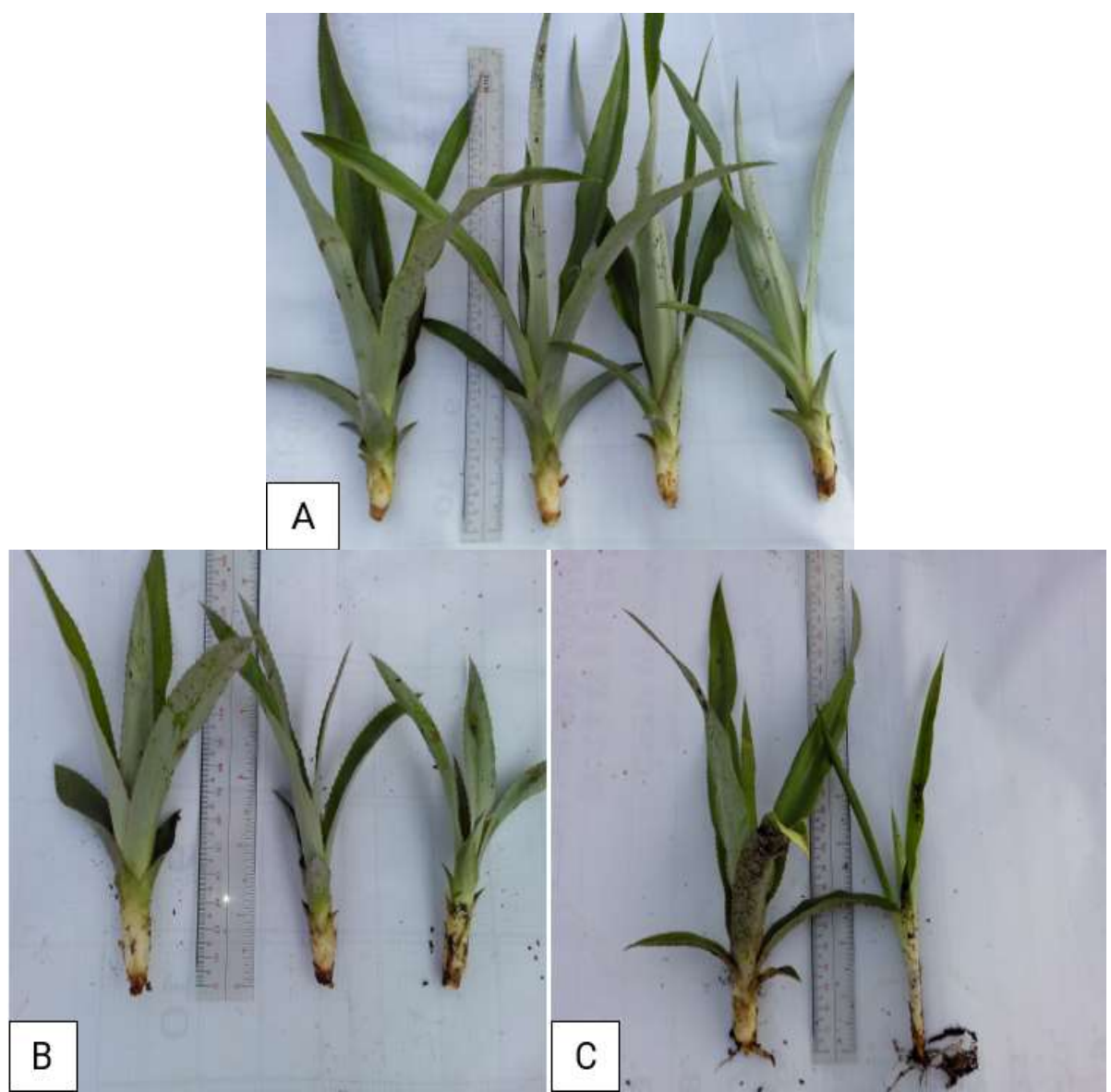

Figure 4. Quality of suckers harvested three months after planting: A) growing point destroyed without splitting $\left(T_{2}\right) ; B$ growing point destroyed crown split into two $\left.\left(T_{3}\right) ; C\right)$ growing point destroyed crown splitinto four $\left(T_{4}\right)$

\section{Survival of Potted Suckers}

Percent survival of potted suckers did not significantly vary among suckers harvested from different plantlets (Table 3). Numerically, suckers from $T_{2}$ had slightly higher $(99.43 \%)$ survival followed by suckers from $T_{4}(97.21 \%)$ and 
suckers from $T_{3}(95.21 \%)$. The slightly higher percent survival among suckers harvested from three kinds of plantlets was attributed to the high quality of the crowns used, having been produced from an established commercial farm (Larazabal Pineapple Farm) which implemented the recommended cultural practices, particularly on crop nutrition. Furthermore, the good quality potting medium used in the study may have also improved sucker survival.

Table 3. Percent survival of potted suckers from pineapple var. Queen crown subjected to 4 methods of crown preparation $^{\text {ns }}$

\begin{tabular}{lc}
\hline \multicolumn{1}{c}{ Treatments } & \% Survival \\
\hline $\mathrm{T}_{1}-$ control: growing point intact & - \\
$\mathrm{T}_{2}$ - growing point destroyed without splitting crowns & 99.43 \\
$\mathrm{~T}_{3}$ - growing point destroyed and crown splitted into two & 95.21 \\
$\mathrm{~T}_{4}-$ growing point destroyed and crown splitted into four & 97.21 \\
\hline $\mathrm{CV}(\%)$ & 3.41 \\
\hline
\end{tabular}

$(-)$ no sucker produced

\section{Sucker Orientation}

All suckers produced by the three types of plantlets exhibited similar erect orientation and were clasping to the mother plantlet (Figure 5).

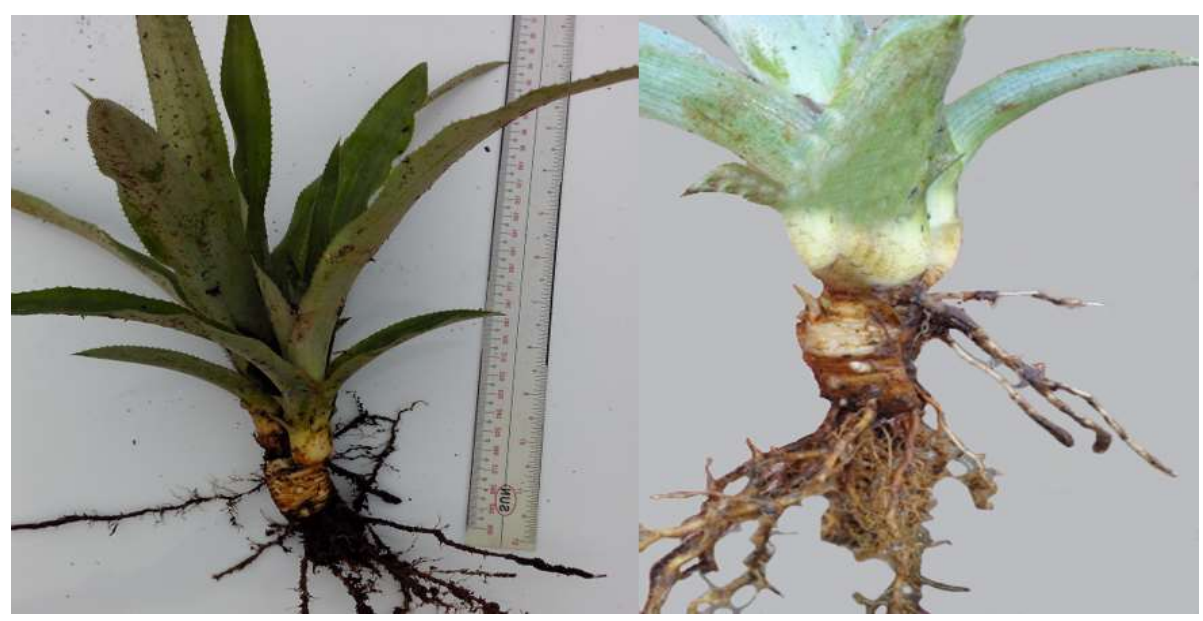

Figure 5. Sucker orientation of suckers from pineapple var. Queen crown subjected to 4 methods of crown preparation 
Split crown technique for mass propagation of pineapple

Tables 4, 5, 6 and 7 show the trend of sucker height, number of leaves, leaf length and width as influenced by the type of plantlets where these were harvested during the first 6 months from potting. There were no significant differences on all four growth parameters evaluated at three sampling periods. Despite of the initial differences as early as two months from potting in height and leaf length of the harvested suckers between $T_{2}$, and $T_{3}$, as well as $T_{4}$ (Table 3), the height and leaf length differences among the said treatments were no longer significant. The comparable growth of the potted suckers could be attributed again to the high quality of the crown where these were harvested. Furthermore, the good quality potting medium used and the fertilization scheme employed may have also improved the growth of the suckers, which is generally fast during their early vegetative stage of growth (Datocos 2013). The results of the present study imply that ready-to-plant-sized suckers can be produced from the pineapple var. Queen crown subjected to meristem destruction and splitting within 5 months from the planting of plantlets ( 3 months for sucker production plus additional two months for sucker development).

\section{CONCLUSIONS}

1. The method of crown preparation significantly affected survival and sucker production (emergence \& number). Destroying the growing point without splitting reduced percentage survival of plantlets, but destroying the growing point and splitting the crown into two and or four sections improved survival comparable to the intact crown. Destruction of the growing point and then splitting the crown promoted emergence and increased number of suckers relative to the intact crown, which did not produce suckers after 3 months from planting. Increasing the number of sections prepared per crown from two to four did not reduce the number of suckers produced per plantlet and thus increased the multiplication rate by 7 and 8 times, respectively.

2. Destroying the growing point without splitting the crown produced suckers which were taller and with longer leaves compared to suckers produced by plantlets from crown with growing point destroyed and split into two and four sections. Splitting the crown into 4 produced suckers with more roots, compared to suckers produced by plantlets prepared following the other two methods of crown preparation. The method of crown preparation did not significantly influence the early growth performance (survival, height, number \& size of leaves) of the harvested suckers during the first 6 months from potting. Among the three methods of crown preparation, destroying the meristem and splitting into two or four produced more number of ready-to-plant Queen pineapple suckers (1-ft tall), within a period of 5 months. 
Ravelo \& Ramos

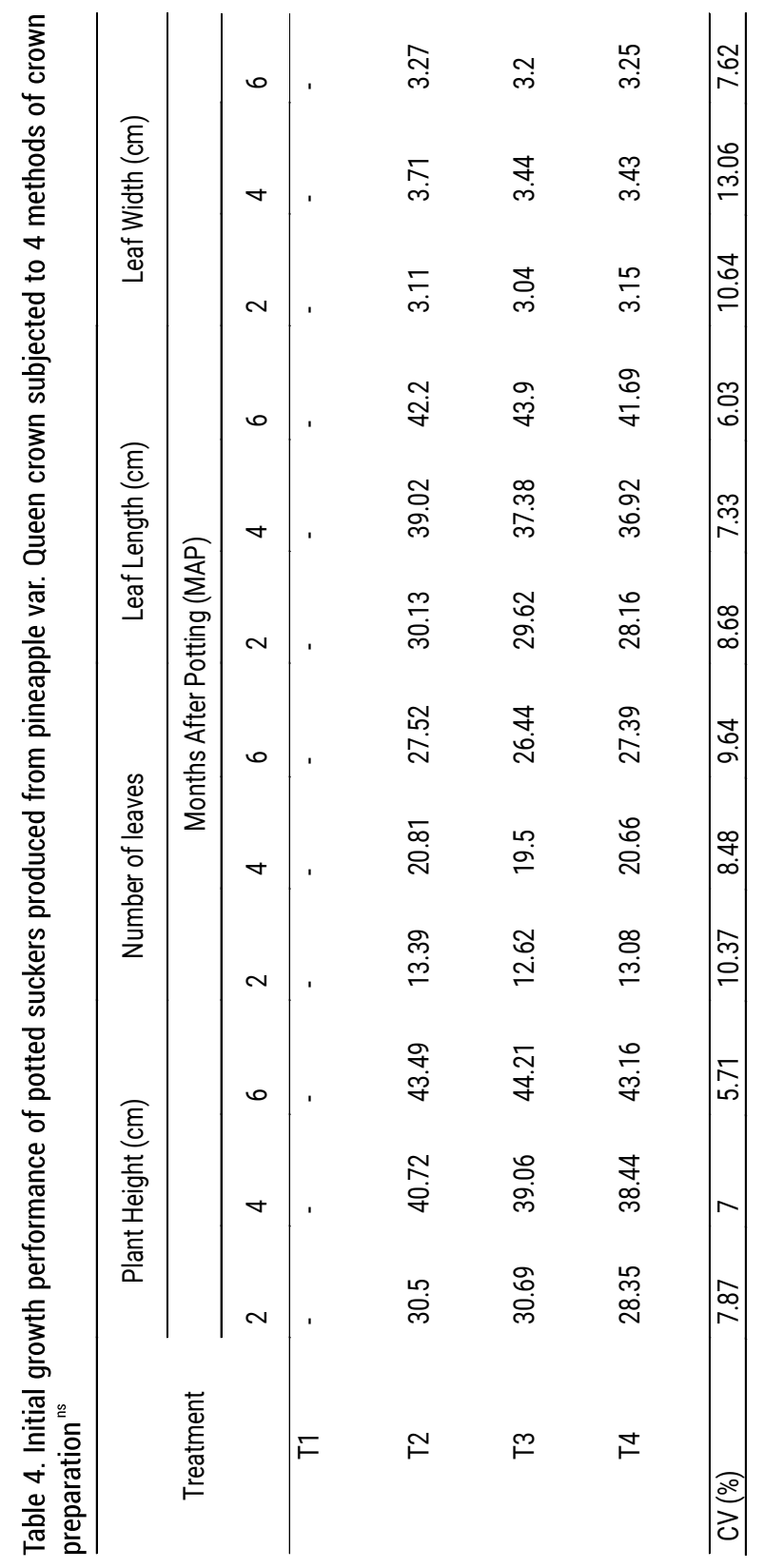


Split crown technique for mass propagation of pineapple

\section{ACKNOWLEDGMENT}

This paper is based on the MS thesis of the first author (SMR). The authors thank the Department of Science and Technology-Science Education Institute (DOST-SEI) for the Accelerated and Technology Human Resource Development Project (ASTHRDP)-National Science Consortium (NSC) thesis grant.

\section{REFERENCES}

Abul-Soad AA, Boshra ES \& Ali HS. 2006. An improved protocol for the micropropagation of pineapple (Ananas comusus L. Merill). Assiut Journal of Agricultural Sciences 37(3):13-30

Adelaja BA. 2000. Rapid On-Farm Propagation Techniques for Plantain and Banana. In Craenen K, Ortiz R, Karamura E \& Vuylsteke D (eds) Proceedings of 1 st International Symposium on Banana and Plantains for Africa. Acta Hoticulturae 540: 279-283

Agogbua $\mathrm{J}$ and Osuji J. 2011. Split crown technique for mass propagation of smooth cayenne pineapple in South-South Nigeria. African Journal of Plant Science 5(10):591-598

Baiyeri KP and Aba SC. 2005. Response of Musa species to macropropagation, I: Genetic and initiation media effects on number, quality and survival of plantlets at pre-nursery and early nursery stages. African Journal Biotechnology 4(3): 223-228

Balito LP. 2011. The Philippine pineapple industry. Acta Horticulturae 902:53-62

Bartolomew DP, Paull RE \& Rohrbach KG. 2003. In Batholomew DP, Paull RE \& Rohrbach KG (eds) The pineapple: botany, production and uses (pp1-301). $\mathrm{CABI}$ publishing, Wallingford, UK

Espino RRC and Espino MRC. 2015. The Status of Fruit Industry in the Philippines. Food and Fertilizer Technology Center. Crop Science Cluster. College of Agriculture, University of the Philippines, Los Baños, Laguna, Philippines

Food and Agricultural Organization of the United Nation (FAO). 2010. Plant Production and Protection Paper 195. Protocols and standards for vegetatively propagated crop. FAO, United Nations, Rome

Firoozabady E, Heckert M \& Gutterson N. 2003. In Firoozabady E (ed) Transformation and regeneration of pineapple. Plant cell, Tissue and Organ Culture 84:1-16

Fitchet $\mathrm{M}$ and Venter HA. 1987. Rapid vegetative propagation of pineapples by cross sectioning. South African Journal of Plant and Soil 5(1):27:31

Green $\mathrm{J}$ and Nelson S. 2015. Heart and root rots of pineapple. Department of tropical plant and soil sciences. Plant disease PD-106. College of tropical agriculture and human resources, University of Hawai, Manoa

Gocal GF, Pharis RP, Yeung EC \& Pearce D. 1991. Changes after Decapitation in Concentrations of Indole-3-Acetic Acid and Abscisic Acid in the Larger Axillary Bud of Phaseolus vulgaris L. cv Tender Green. Plant Physiology 95(2):344-350

Philippine Statistics Authority. 2016. Crop statistics of the Philippines (2012-2016). Accessed from https://psa.gov.ph/sites/default/files/Crops\%20Statistics\%2 0of\%20the\%20Philippines\%2C\%202012-2016.pdf 
Liu J, Mukherjee I \& Reid DM. 1990. Adventitious rooting in hypocotyls of sunflower (Helianthus annuus) seedlings. III. The role of ethylene. Physiologia Plantarium 78(2):268-276

Lopez FG. 1994. Rapid technique for plantain multiplication on Columbia. INFOMUSA 3(2): 7

Negi S, Sukumar P, Liu X, Cohen JD \& Muday JK. 2010. Genetic desection of the role of ethylene in regulating auxin-dependent lateral and adventitious root formation in tomato. The Plant Journal 61(1):3-15

Pan R, Wang J \& Tian X. 2001. Influence of ethylene on adventitious root formation in mungbean hypocotyl cuttings. Plant Growth Regulation 36(2):135-139

Pardales JR and Dalion SS. 1986. Methods for rapid vegetative propagation of taro. Tropical Agriculture (Trinidad and Tobago) 63(4):278-280

Purseglove JW. 1975. Bromeliaceae. In Tropical Crops, Monocotyledons (pp7590). Longmans, Green and Co. Ltd., London

Rahman KW, Amin MN \& Azad MAK .2001. In vitro rapid propagation of pineapple clones, Ananas comosus (L.) Merr. Plant Tissue Culture 11(1):47-53

Roy B, Basu R \& Bose T.1972. Interaction of auxins with growth-retarding,-inhibiting and ethylene-producing chemicals in rooting of cuttings. Plant and Cell Physiology 13(2):1123-1127

Spirko LS and Rossi AM. 2015. Manner of apical meristem destruction affects growth, reproduction, and survival of sea oxeye daisy. Journal of Botany 2015:1-11

Sripaoraya S, Marchant R, Power JB \& Davey MR. 2003. Plant regeneration by somatic embryogenesis and organogenesis in commercial pineapple (Ananas comosus L.). In Vitro Cellular \& Developmental Biology-Plant 39(5):450-454

Swennen R. 1990. Plantain cultivation under West African Conditions: A reference Manual (pp1-24). International Institute of Tropical Agriculture, Ibadan, Nigeria 